\title{
RISIKO PRODUKTIVITAS AKAR WANGI DI KABUPATEN GARUT
}

\author{
Productivity Risk Of Wangi Root \\ In Garut District
}

\author{
Vela Rostwentivaivi' ${ }^{1)}$, Kurnaeli ${ }^{1)}$ \\ ${ }^{1)}$ Fakultas Pertanian, Universitas Garut \\ E-mail : velasinaga@uniga.ac.id \\ rellykur@yahoo.co.id
}

\begin{abstract}
Indonesia is the second largest producer of vetiver after the country of Haiti. The biggest center of vetiver is in Garut Regency which is able to contribute about 90 percent of the total production of essential oils of vetiver in Indonesia. The production of fresh fragrant roots in Garut Regency has decreased from 2012-2016. This is due to the decline in world essential oil prices. Vetiver cultivation is a side job for most farmers in Garut Regency because this commodity can only be harvested at the age of 12 months. Farmers cultivate using a polyculture system in one field, with the hope that farmers can generate monthly income. Not only essential oils that can be produced by fragrant roots, handicraft products can also increase added value. The study was conducted in four sub-districts with 89 vetiver farmers in Garut Regency. The data taken is the production data in 2017. The method used in the study is the Just and Pope model. This model has accommodated risks in the production equation by including the variance of the production equation. The coefficient of variation is used to calculate the risk of production. The results showed that there were 5 variables that affected the productivity of vetiver, including land, weevils, manure, chemical fertilizers, and labor. Variables of manure, chemical fertilizers and labor can increase the risk indicated by a positive sign. While the variable land and vetiver hump is indicated by a negative sign which means it can reduce risk.
\end{abstract}

Keywords: Risk, Productivity, Wangi Root, Garut

\section{ABSTRAK}

Indonesia adalah produsen akar wangi terbesar kedua setelah negara Haiti. Sentra akar wangi terbesar berada di Kabupaten Garut yang mampu menyumbang sekitar 90 persen dari total produksi minyak atsiri akar wangi di Indonesia. Produksi akar wangi segar di Kabupaten Garut mengalami penurunan dari tahun 2012-2016. Hal ini dikarenakan adanya penurunan harga minyak atsiri dunia. Budidaya akar wangi menjadi pekerjaan sampingan bagi sebagian besar petani di Kabupaten Garut karena komoditas ini baru dapat dipanen pada usia 12 bulan. Petani melakukan budidaya menggunakan sistem polikultur dalam satu lahan, dengan harapan petani mampu menghasilkan pendapatan bulanan. Tidak hanya minyak atsiri yang dapat dihasilkan akar wangi, produk kerajinan juga mampu meningkatkan nilai tambah. Penelitian dilaksanakan di empat kecamatan dengan 89 petani akar wangi di Kabupaten Garut. Data yang diambil adalah data produksi di tahun 2017. Metode yang digunakan dalam penelitian adalah model Just and Pope. Model ini telah mengakomodasi risiko dalam persamaan produksi dengan memasukkan varians dari persamaan produksi. Koefisien variasi digunakan untuk menghitung risiko produksi. Hasil penelitian menunjukkan bahwa terdapat 5 variabel yang memengaruhi produktivitas akar wangi, diantaranya lahan, bonggol, pupuk kandang, pupuk kimia, dan tenaga kerja. Variabel pupuk kandang, pupuk kimia dan tenaga kerja mampu meningkatkan risiko yang ditunjukkan dengan tanda positif. Sedangkan variabel lahan dan bonggol akar wangi ditunjukkan dengan tanda negatif yang berarti dapat mengurangi risiko.

Kata Kunci : Risiko, Produktivitas, Akar Wangi, Garut

\section{PENDAHULUAN}

Indonesia adalah produsen akar wangi kedua terbesar setelah negara Haiti. Akar wangi (Vetiveria zizanoides L.) merupakan tanaman yang tumbuh baik di Kabupaten Garut dengan iklim tropis pada ketinggian 500-1.500 mdpl, curah hujan 1.500$2.500 \mathrm{~mm}$ per tahun, suhu $17-27^{\circ} \mathrm{C}$, derajat keasaman tanah $(\mathrm{pH})$ 6-7 dan curah hujan cukup mencapai 140 hari per tahun. Akar wangi dipanen pada usia di atas 8 bulan. Kabupaten Garut menyumbang 90 persen dari total produksi minyak 
atsiri akar wangi di Indonesia, yaitu 50-75 ton per tahun. Tidak semua kecamatan di Kabupaten Garut yang cocok ditanam akar wangi, hanya terdapat 6 kecamatan yang merupakan area penanaman akar wangi yaitu Cilawu, Samarang, Bayongbong, Leles, Tarogong Kaler, dan Pasirwangi. Selain minyak atsiri, akar wangi dapat diolah menjadi produk kerajinan yang memiliki nilai tambah tinggi. Lebih dari 100 produk kerajinan sudah terjual di pasar domestik maupun pasar luar negeri.

Produksi akar wangi segar di Kabupaten Garut mengalami penurunan dari tahun 2012-2016 (Dinas Pertanian Kabupaten Garut, 2017). Penurunan produksi disebabkan beralihnya petani melakukan budidaya tanaman hortikultura sebagai usaha utama mereka. Budidaya akar wangi hanya menjadi pekerjaan sampingan sebagian besar petani di Kabupaten Garut karena akar wangi dapat dipanen hanya satu kali dalam satu tahun. Petani membudidayakan komoditas hortikultura untuk memenuhi kebutuhan hidupnya. Harga minyak atsiri terlihat mengalami peningkatan dari tahun 2015 dengan harga rata-rata Rp. 1.250.000,- per kg hingga mencapai sekitar Rp. 4.000.000,- per kg pada tahun 2017.

Permintaan minyak atsiri akar wangi diperkiran mencapai 300 ton per tahun, sedangkan pemenuhan pasar minyak atsiri Indonesia sekitar 50 ton per tahun. Kondisi ini mengindikasikan terbukanya peluang untuk memenuhi permintaan pasar dunia. Pemasaran minyak atsiri seluruhnya didistribusikan ke perusahaan ekspor yang berada di wilayah Jakarta dan Bogor. Industri pengolahan minyak atsiri melakukan kerjasama dengan perusahaan ekspor. Di sisi lain, industri kerajinan mengalami kesulitan dalam pemenuhan pasokan bahan baku untuk kebutuhan pasar domestik maupun luar negeri.

\section{KAJIAN PUSTAKA}

Kegiatan usaha yang semakin kompleks mampu menimbulkan risiko. Risiko didefinisikan kemungkinan kejadian yang merugikan (Kountur, 2006). Model Just and Pope (1979) telah mengakomodasi risiko dalam persamaan produksi dengan memasukkan varians dari persamaan produksi. Koefisien variasi digunakan untuk menghitung risiko produksi (Suharyanto et al., 2015) dan risiko harga.

Menurut Rochdiani (2008) permasalahan yang dirasakan petani akar wangi adalah keterbatasan modal, produktivitas, pemasaran dan kemampuan petani untuk bergerak di bidang off-farm serta masih lemahnya kemampuan asosiasi petani baik dalam hal permodalan maupun sumber daya manusia yang menyebabkan pendapatan petani cenderung rendah. Jamilah et al., (2011) menegaskan faktor curah hujan, musim, kelembaban, bencana alam, teknologi serta input termasuk dalam sumber risiko.

\section{METODE PENELITIAN}

Lokasi penelitian dilakukan pada empat kecamatan di Kabupaten Garut, yaitu Cilawu, Samarang, Bayongbong, dan Leles. Penentuan lokasi penelitian merupakan area produksi tertinggi akar wangi sehingga dapat merepresentasikan total produksi akar wangi Kabupaten Garut. Responden yang diwawancarai terdiri dari 89 orang petani akar wangi, diantaranya 34 responden (Cilawu), 29 responden (Samarang), 1 responden (Leles), dan 25 responden (Bayongbong). Teknik pengambilan responden dengan judgement sampling, yaitu berdasarkan referensi dari penyuluh pertanian. Metode dalam penelitian ini adalah analisis fungsi produksi Just and Pope.

$$
\mathbf{Y}=\mathbf{f}(\mathbf{x}, \boldsymbol{\beta})+\mathbf{h}(\mathbf{x}, \boldsymbol{\theta}) \boldsymbol{\varepsilon}
$$

$\mathrm{Y}=$ Hasil produktivitas

\begin{tabular}{|c|c|c|}
\hline \multirow[t]{2}{*}{$f$} & $=$ & Bentuk hubungan yang \\
\hline & & $\begin{array}{l}\text { mentranformasikan } \\
\text { produksi dalam rata rata hasil } \\
\text { produktivitas }\end{array}$ \\
\hline \multirow[t]{3}{*}{ h } & $=$ & Bentuk hubungan \\
\hline & & mentranformasikan \\
\hline & & $\begin{array}{l}\text { produksi dalam variance hasil } \\
\text { produktivitas }\end{array}$ \\
\hline $\mathrm{x}$ & $=$ & $\begin{array}{l}\text { Faktor-faktor produksi yang digunakan } \\
\text { dalam proses produksi (input) }\end{array}$ \\
\hline & $=$ & Besaran yang akan diduga \\
\hline & $=$ & Error \\
\hline
\end{tabular}

Model risiko fungsi produksi Just and Pope, yaitu :

$$
\begin{aligned}
& \mathrm{Y}=\mathrm{f}(\mathrm{x}) \\
& \operatorname{Ln} Y=\operatorname{Ln} \beta+\beta_{1} \operatorname{LnX}_{1}+\beta_{2} \operatorname{LnX}_{2}+\beta_{3} \operatorname{LnX}_{3}+ \\
& \beta_{4} \operatorname{LnX}_{4}+\beta_{5} \operatorname{LnX} X_{5}+\varepsilon \\
& \text { Dan } \\
& \operatorname{Ln} \sigma_{2} \mathrm{y}=\operatorname{Ln} \theta+\theta_{1} \operatorname{LnX}_{1}+\theta_{2} \operatorname{LnX}_{2}+\theta_{3} \operatorname{LnX}_{3}+ \\
& \theta_{4} \operatorname{LnX}_{4}+\theta_{5} \operatorname{LnX}_{5}+\theta \\
& \mathrm{Y}=\text { Produktivitas akar wangi } \\
& \mathrm{X}_{1} \quad=\quad \text { Lahan (tumbak) } \\
& \mathrm{X}_{2} \quad=\quad \text { Bonggol bibit per siklus } \\
& \mathrm{X}_{3} \quad=\quad \begin{array}{l}
\text { (kg/tumbak) } \\
\text { Pupuk }
\end{array} \\
& \mathrm{X}_{4} \quad=\quad \begin{array}{l}
\text { (karung/tumbak) } \\
\mathrm{X}_{5}
\end{array} \\
& \mathrm{X}_{5} \quad=\quad \text { Tenaga Kerja (HOK/tumbak) } \\
& \beta \quad=\quad \text { Mean intercept } \\
& \theta \quad=\quad \text { Variance intercept } \\
& \mathrm{E} \quad=\quad \text { Error term } \\
& \beta_{1}, \beta_{2}, \ldots, \beta_{5}=\text { Koefisien parameter dugaan } \\
& \mathrm{X} 1, \mathrm{X} 2, \ldots, \mathrm{X} 5 \\
& \theta_{1}, \theta_{2}, \ldots, \theta_{5}=\text { Koefisien parameter dugaan } \\
& \mathrm{X} 1, \mathrm{X} 2, \ldots, \mathrm{X} 5
\end{aligned}
$$




\section{Hipotesis :}

Jika $\beta 1, \beta 2, \ldots, \beta 5>0$, artinya semakin banyak input $\mathrm{X}$ yang digunakan dalam proses produksi maka rata-rata hasil produktivitas akar wangi dalam suatu lahan akan meningkat.

Jika $\theta 1, \theta 2, \ldots, \theta 5>0$, artinya semakin banyak input $\mathrm{X}$ yang digunakan dalam proses produksi maka variasi hasil produktivitas akar wangi dalam suatu lahan akan semakin meningkat.
Hasil pendugaan persamaan produktivitas dan varians aka wangi menunjukkan R2 sebesar 62,37 persen. Berarti keragaman atau variasi produksi dapat dijelaskan bersama-sama oleh model dan sisanya 37,63 persen dijelaskan oleh komponen error. Pengujian Durbin Watson bertujuan untuk melihat autokorelasi dan mensyaratkan intercept (konstanta) dalam model regregi dan tidak ada variabel lag di antara variabel bebas. Nilai Durbin Watson sebesar 2 yang dapat disimpulkan data yang ada telah menyebar normal. Penjelasan lengkapnya dapat dilihat pada Tabel 1.

\section{HASIL PENELITIAN DAN PEMBAHASAN}

Tabel 1. Hasil Pendugaan Persamaan Fungsi Produktivitas dan Variance Produktivitas Akar Wangi di Kabupaten Garut

\begin{tabular}{|c|c|c|c|c|}
\hline Variable & Coefficient & Std. Error & z-Statistic & Prob. \\
\hline Konstanta & 24.97928 & 1.822388 & 13.70689 & 0.0000 \\
\hline Lahan $\left(\mathrm{X}_{1}\right)$ & -1.389901 & 0.516637 & -2.690284 & 0.0071 \\
\hline Bonggol Akar Wangi $\left(\mathrm{X}_{2}\right)$ & -0.426698 & 0.609540 & -0.700034 & 0.4839 \\
\hline Pupuk Kandang $\left(\mathrm{X}_{3}\right)$ & 0.017224 & 0.174237 & 0.098856 & 0.9213 \\
\hline Pupuk Kimia $\left(\mathrm{X}_{4}\right)$ & -0.833150 & 0.291175 & -2.861341 & 0.0042 \\
\hline Tenaga Kerja $\left(X_{5}\right)$ & -0.715486 & 0.494989 & -1.445458 & 0.1483 \\
\hline \multicolumn{5}{|c|}{ Variance Equation } \\
\hline Konstanta & -0.391144 & 4.104489 & -0.095297 & 0.9241 \\
\hline $\begin{array}{l}\text { Error Kuadrat Musim Sebelumnya } \\
\left(\varepsilon_{\mathrm{t}-1}^{2}\right)\end{array}$ & -0.054066 & 0.030874 & -1.751202 & 0.0799 \\
\hline $\begin{array}{l}\text { Variance Error Musim } \\
\text { Sebelumnya }\left(\sigma_{t-1}^{2}\right)\end{array}$ & 0.795392 & 0.159290 & 4.993370 & 0.0000 \\
\hline Lahan $\left(\mathrm{X}_{1}\right)$ & -0.738996 & 1.066853 & -0.692688 & 0.4885 \\
\hline Bonggol Akar Wangi $\left(\mathrm{X}_{2}\right)$ & -0.798919 & 1.083720 & -0.737200 & 0.4610 \\
\hline Pupuk Kandang $\left(\mathrm{X}_{3}\right)$ & 0.836549 & 0.286327 & 2.921652 & 0.0035 \\
\hline Pupuk Kimia $\left(\mathrm{X}_{4}\right)$ & 0.869069 & 0.685446 & 1.267888 & 0.2048 \\
\hline Tenaga Kerja $\left(\mathrm{X}_{5}\right)$ & 0.747795 & 1.414721 & 0.528581 & 0.5971 \\
\hline R-squared & 0.623792 & Mean dependent var & & 5.382022 \\
\hline Adjusted R-squared & 0.601129 & S.D. dependent var & & 4.841829 \\
\hline S.E. of regression & 3.057916 & Akaike info criterion & & 4.991588 \\
\hline Sum squared resid & 776.1204 & Schwarz criterion & & 5.383059 \\
\hline Log likelihood & -208.1257 & Hannan-Quinn criter. & & 5.149378 \\
\hline Durbin-Watson stat & 2.063972 & & & \\
\hline
\end{tabular}

Sumber : Data Olahan

\section{Lahan (X1)}

Akar wangi tumbuh dengan baik dipengaruhi oleh keadaan tanah dan iklim. Tanaman ini cocok ditanam pada tanah yang berpasir (antosol) atau abu vulkanik di lereng-lereng bukit. Akar wangi membutuhkan $\mathrm{pH}$ sekitar 67, curah hujan 140 hari per tahun, suhu 17$27^{\circ} \mathrm{C}$. Hasil pendugaan parameter koefisien pada variabel lahan menunjukkan tanda negatif dengan nilai -1.389. Hal ini berarti penambahan lahan sebesar 1 persen akan mengurangi produktivitas akar wangi sebesar 1,389 persen (cateris paribus). Penggunaan lahan juga berpengaruh signifikan terhadap tingkat produktivitas akar wangi dengan nilai dibawah 1 persen.

Variabel lahan memiliki nilai negatif pada variance equation dengan nilai -0.738 . nilai ini memiliki arti semakin banyak lahan yang digunakan maka variasi hasil produksi akar wangi akan menurun. Dengan kata lain, lahan dapat mengurangi risiko yang ada. Hasil pendugaan persamaan fungsi varians produktivitas mempunyai taraf nyata 48 persen yang menunjukkan penggunaan lahan tidak 
berpengaruh signifikan terhadap tingkat variasi produksi akar wangi karena taraf nyatanya melebihi 20 persen.

\section{Bonggol Akar Wangi (X2)}

Bonggol akar wangi dapat digunakan secara terus menerus tanpa harus membeli bonggol baru sebagai bibit. Parameter bonggol akar wangi menunjukkan nilai negatif sebesar 0.426. Nilai ini memiliki arti bila bonggol akar wangi ditambah sebesar 1 persen maka akan mengurangi produktivitas akar wangi sebesar 0,426 persen (cateris paribus). Hasil pendugaan parameter menunjukkan nilai 48 pesen yang menunjukkan penggunaan bonggol akar wangi tidak berpengaruh signifikan terhadap tingkat produktivitas akar wangi. Secara agronomis, penggunaan bibit secara terus menerus akan menurunkan hasil panen, baik kualitas maupun kuantitasnya.

Parameter variabel bonggol akar wangi memiliki nilai negatif sebesar -0.798 yang berarti penggunaan bonggol akar wangi dapat mengurangi risiko. Hasil pendugaan persamaan fungsi varians produktivitas akar wangi menunjukkan taraf nyata 46 persen sehingga penggunaan bonggol akar wangi tidak berpengaruh signifikan terhadap tingkat variasi hasil produksi akar wangi.

\section{Pupuk Kandang (X3)}

Pupuk kandang merupakan pupuk dasar yang digunakan untuk penggemburan dan penambahan unsur hara. Pemberian pupuk kandang dilakukan sebelum penanaman akar wangi di lahan. Parameter koefisien bertanda positif dengan nilai 0.017 yang memiliki arti pupuk kandang ditambah 1 persen akan meningkatkan produktivitas akar wangi sebesar 0,017 persen (cateris paribus). Kemungkinan (probability) variabel pupuk kandang menunjukkan nilai 92 persen sehingga penggunaan pupuk ini tidak berpengaruh signifikan terhadap tingkat produktivitas akar wangi.

Parameter variabel pupuk kandang memiliki nilai positif sebesar 0,836 . Nilai ini menunjukkan pupuk kandang dapat meningkatkan risiko. Pendugaan persamaan fungsi varians produktivitas akar wangi menunjukkan variabel pupuk kandang mempunyai taraf nyata dibawah 1 persen. Hal ini berarti penggunaan pupuk kandang berpengaruh signifikan terhadap tingkat variasi hasil produksi akar wangi. Pupuk kandang memberikan andil dalam persaingan ruang tumbuh antara tanaman akar wangi dan hortikultura.

\section{Pupuk Kimia (X4)}

Petani menggunakan pupuk kimia yang bertujuan merangsang pertumbuhan tanaman.
Parameter koefisien memiliki niai negatif sebesar -0.833. Nilai ini memiliki arti jika pupuk kimia ditambah 1 persen maka akan mengurangi produktivitas akar wangi sebesar 0,833 (cateris paribus). Hasil pendugaan parameter pada persamaan fungsi produksi ratarata dibawah 1 persen yang berarti penggunaan pupuk kimia berpengaruh signifikan terhadap tingkat produktivitas akar wangi.

Parameter variabel pupuk kimia memiliki nilai positif sebesar 0,869 , yang berati dapat meningkatkan risiko. Hasil pendugaan persamaan fungsi varians produktivitas akar wangi menunjukkan variabel pupuk kimia mempunyai taraf nyata diatas 20 persen sehingga tidak berpengaruh signifikan terhadap tingkat variasi hasil produksi akar wangi.

\section{Tenaga Kerja (X5)}

Tenaga kerja memiliki parameter koefisien dengan nilai -0.715 yang memiliki arti lahan ditambah sebesar 1 persen akan mengurangi produktivitas akar wangi sebesar 0,715 persen (cateris paribus). Hasil pendugaan parameter pada persamaan fungsi produksi rata-rata menunjukkan nilai 14 persen. Hal ini berarti penggunaan tenaga kerja tidak berpengaruh signifikan terhadap tingkat produktivitas akar wangi.

Parameter variabel tenaga kerja bernilai positif sebesar 0.747. Nilai ini berarti tenaga kerja dapat meningkatkan risiko. Taraf nyata sebesar 59 persen memiliki arti bahwa tenaga kerja tidak berpengaruh signifikan terhadap tingkat variasi hasil produksi akar wangi. pemakaian tenaga kerja tentunya akan mengeluarkan biaya yang cukup besar. Khusus tanaman akar wangi, penggunaan tenaga kerja tidak terlalu besar karena perawatan tanaman ini yang relatif lebih mudah bila dibandingkan dengan hortikultura.

\section{KESIMPULAN}

Kesimpulan dari penelitian ini adalah variabel pupuk kandang, pupuk kimia dan tenaga kerja mampu meningkatkan risiko yang ditunjukkan dengan tanda positif. Sedangkan variabel lahan dan bonggol akar wangi ditunjukkan dengan tanda negatif yang berarti dapat mengurangi risiko.

\section{UCAPAN TERIMAKASIH}

Penulis mengucapkan terimakasih kepada Kementerian Riset, Teknologi dan Pendidikan Tinggi Republik Indonesia (Kemenristekdikti) tentang pelaksanaan Penelitian Dosen Pemula (PDP) program hibah tahun 2018. Semoga hasil penelitian ini dapat bermanfaat dan memberikan kontribusi untuk pengetahuan. 


\section{DAFTAR PUSTAKA}

Jamilah M, Nurhayati P. 2011. Analisis Risiko Produksi Wortel Dan Bawang Daun di Kawasan Agropolitan Cianjur Jawa Barat. Forum Agribisnis. Vol 1 (1): 1-19.

Kountur R. 2006. Manajemen Risiko. Jakarta: Abdi Tandur.

Rochdiani, D. 2008. Pola Pendapatana Petani Akar Wangi Di Kecamatan Samarang Kabupaten Garut Provinsi Jawa Barat. Jurnal Agrikultura. 19(3): 201-207.

Suharyanto, Rinaldy J, Arya N.N. 2015. Analisis Risiko Produksi Usahatani Padi Sawah di Provinsi Bali. Jurnal Agraris. Vol 1 (2): 7077. 
Filename:

4-VELA_82DE0E2F

Directory:

C: UUsers\user\AppData\Local\Temp

Template:

C:\Users\user\AppData\Roaming\Microsoft \Templates\Normal.dot

$\mathrm{m}$

Title:

Subject:

Author:

Windows User

Keywords:

Comments:

Creation Date: $\quad$ 11/12/2018 19:24:00

Change Number: $\quad 6$

Last Saved On: $\quad$ 11/12/2018 20:02:00

Last Saved By: user

Total Editing Time: $\quad 31$ Minutes

Last Printed On: $\quad$ 11/12/2018 21:44:00

As of Last Complete Printing

Number of Pages: 5

Number of Words: 2.319 (approx.)

Number of Characters: 14.286 (approx.) 